\title{
Tanggung Jawab Perusahaan Dalam Komersialisasi Ruang Angkasa dan Implikasinya Terhadap Outer Space Treaty 1967 (Studi Tentang Wisata Ruang Angkasa)
}

\author{
Niken Tyasworo*; Mas Nana Jumena \\ Fakultas Hukum Universitas Sultan Ageng Tirtayasa \\ *Corresponding author: nikentyasworo1902@gmail.com \\ Submission $\quad: 27$ Februari 2021 \\ Revision : 21 Mei 2021 \\ Publication : 02 Juni 2021
}

\begin{abstract}
The exploratory utilization of outer space is currently take a place following the development of science and technologies. At first, the exploration was done by government only, in this time, private companies also take part to do the outer space exploration.The outer space tour activities is one form of outer space commercialization. This time, those activities is still in the developing process for the better future business, especially in the law aspect for the outer space tour activities. So that, an explanation of the outer space tour activity is one particular part that should be extremely clear and understandable for the sake of tourist's security. Such as, how far the responsibility is given by government and private companies in case of an accident during the outer space tour activities.The conclusion of this research is to mention that Outer Space Treaty 1967, Rescue Agreement 1968, Liability Convention 1972 and Registration Convention 1975 are all be able to applied as basic law for the outer space tour activities. Therefore, the outer space tour activity is something that could have been done routinely in the future and that makes the laws and regulations must be evident, equitable, and liable in order to ensure comfort and safety for the outer space tourists.
\end{abstract}

Keyword: Exploration; Outer Space; Space Tourism. 


\begin{abstract}
Abstrak
Eksplorasi pemanfaatan ruang angkasa terjadi dengan sangat cepat mengikuti perkembangan ilmu pengetahuan dan teknologi yang ada. Eksplorasi pemanfataan ruang angkasa yang pada mulanya hanya dilakukan oleh negara, tetapi dalam perkembangannya pihak swasta juga melakukan eksplorasi ruang angkasa. Kegiatan wisata ruang angkasa merupakan salah satu bentuk dari komersialisasi ruang angkasa. Saat ini, kegiatan tersebut masih dalam tahap pengembangan menuju bisnis masa depan yang lebih baik. Sehingga, penjelasan seputar kegiatan wisata ruang angkasa adalah hal yang patut diketahui seluk-beluknya, terutama mengenai hukum yang melindungi wisatawan, seperti sejauh mana tanggung jawab yang diberikan oleh negara dan perusahaan pengangkut apabila terjadi kecelakaan saat kegiatan wisata ruang angkasa. Dalam penelitian yang dilakukan dapat disimpulkan bahwa Outer Space Treaty 1967, Rescue Agreement 1968, Liability Convention 1972 dan Registration Convention 1975 dapat digunakan menjadi dasar hukum kegiatan wisata ruang angkasa. Dengan demikian, kegiatan wisata ruang angkasa adalah kegiatan yang sangat mungkin dilakukan secara rutin di masa yang akan datang, sehingga pengaturannya secara internasional harus jelas, adil dan bertanggung jawab sehingga wisatawan ruang angkasa dapat melakukan kegiatan wisatanya dengan nyaman.
\end{abstract}

Kata Kunci: Eksplorasi; Ruang Angkasa; Wisata Ruang Angkasa.

\title{
A. Pendahuluan
}

Kemajuan ilmu pengetahuan dan teknologi ruang angka satelah sampai pada tahap aplikasinya yang tidak hanya dapat dimanfaatkan untuk kepentingan penelitian dan militer, tapi juga untuk memenuhi kebutuhan kehidupan manusia umumnya. ${ }^{1}$ Terdapat beberapa bentuk kegiatan pemanfaatan ruang angkasa yang sudah ada dan berkembang secara

1 Collins P.Q., Ashford D.M. Potential Economic Implications of The Development of Space Tourism. Acta Astronautica. Vol. 17 Issue 4. April 1988. hal. 421-431. 
potensial, misalnya telekomunikasi, penginderaan jarak jauh, asuransi ruang angkasa, penambangan ruang angkasa dan transportasi ruang angkasa termasuk wisata ruang angkasa (space tourism).

Bergesernya tujuan pemanfaatan ruang angkasa dan bertambahnya pelaku dalam kegiatan ruang angkasa, menunjukkan bahwa manusia dan ruang angkasa telah memasuki tahap komersialisasi ruang angkasa (space commerce). Banyak pengertian yang diberikan atas istilah komersialisasi ruang angkasa, salah satunya adalah pendapat dari Wahyudi Bahar, yaitu komersialisasi ruang angkasa meliputi segala macam kegiatan yang berhubungan dengan ruang angkasa untuk memperoleh keuntungan ekonomis. Kegiatan komersial ini dilakukan baik oleh badan-badan pemerintah atau pun swasta, nasional, maupun internasional ${ }^{2}$.

Wisata ruang angkasa dianggap sebagai salah satu peluang yang menguntungkan dalam bisnis di era modern. Hal ini menjadikan banyak perusahaan swasta yang tertarik untuk fokus bergerak dalam bidang wisata ruang angkasa, contohnya Virgin Galactic yang sudah berhasil meluncurkan pesawat Space Ship Two pada juni 2015, SpaceMExploration Technologies Corporation (Spacex), Orbital ATK, Blue Origin,

2 Wahyudi Bahar. Pertanggungjawaban Negara Terhadap Kegiatan Komersial di Ruang Angkasa dalam Hukum Angkasa dan Perkembangannya. Ed E. Saefullah Wirapradja. et. al. Bandung: Remadja Karya. 1998. hal. 165.

Uti Possidetis: Journal of International Law, Vol. 2, No. 2 (2021) 
Bigelow Aerospace, Space Dev33. Perlindungan bagi para wisatawan kegiatan wisata ruang angkasa merupakan hal yang mutlak dilakukan, karena kegiatan ini memiliki banyak resiko berbahaya. Tercatat pada tahun 2003, pesawat Columbia mengalami kecelakaan yang menyebabkan kerusakan di permukaan bumi. ${ }^{4}$ Ditambah pada tahun 2007 dan 2014 juga tercatat terjadi beberapa kegagalan penerbangan antariksa. ${ }^{5}$ Beberapa catatan kecelakaan tersebut menunjukkan bahwa peluang bisnis wisata antariksa bukan merupakan sesuatu yang bebas risiko melainkan penuh resiko bagi crew, turis, dan crew ditempat peluncuran pesawat maupun terhadap obyek publiklainnya.

Komersialisasi ruang angkasa yang melibatkan sektor swasta semakin meningkat, terutama dinegara-negara maju, namun demikian perangkat hukum yang mengaturnya belum tersedia. Hal ini dapat menimbulkan suatu permasalahan hukum tersendiri dalam kegiatan ruang angkasa. Kegiatan ruang angkasa yang diatur dalam hukum ruang angkasa

3 Redaksi Kumparan. "6 Perusahaan Swasta Ini Berlomba Tawarkan Wisata ke Luar Angkasa”, https://kumparan.com/@ku mparansains /6-perusahaan-swasta-ini-berlomba-tawarkan-wisa ta-ke-luar-angkasa, (di unduh pada tanggal13 Maret 2021. 02:30 WIB)

4 Elizabet Howell. Columbia Disaster: What Happened. What NASA Learned. https://www.space.com/19436-columbia-disaster.html, (di unduh pada tanggal13 Maret 2021. 02:30 WIB)

5 Elizabeth Howell. Virgin Galactic: Richard Branson's Space Tourism Company. https://www.space.com/18993-virgin-gala ctic.html. (di unduh pada tanggal 13 Maret 2021. 02:40 WIB) 
subjeknya adalah negara, sedangkan kegiatan yang dilakukan oleh perusahaan swasta tidak diatur secara jelas. Keterlibatan perusahaan swasta dalam kegiatan ruang angkasa tidak pernah terjadi tanpa adanya ijin dari negara. Oleh karena itu peranan negara dalam mengatur kegiatan ruang angkasa yang dilakukan oleh perusahaan swasta ini sangat penting. ${ }^{6}$

Outer Space Treaty 1967 yang menyatakan bahwa ruang angkasa bebas untuk dieksplorasi dan di eksploitasi oleh semua negara, hal ini menjadi dasar untuk melakukan eksplorasi dan eksploitasi terhadap ruang angkasa. Selain itu juga menjadi dasar terbentuknya perjanjian-perjanjian internasional lainnya dibidang ruang angkasa, salah satunya adalah Rescue Agreement 1968 yang merupakan perjanjian yang mengatur tentang pertolongan bagi astronot dan pesawat ruang angkasa ataupun objek yang diluncurkan keruang angkasa sebagai subjek ataupun objek di dalam perjanjian itu.

Dalam ketentuan yang terdapat di Outer Space Treaty 1967 dan Rescue Agreement 1968 terdapat berbagai perlindungan untuk kegiatan diruang angkasa seperti adanya tanggung jawab Internasional yang harus dilakukan oleh negara yang melaksanakan kegiatan di ruang angkasa, diberikannya ganti rugi atas kerusakan yang diakibatkan oleh kegiatan ruang angkasa, serta perlindungan dengan bentuk

6 Sri Wartini. Pertanggungjawaban Negara Dalam Kegiataan Komersiil Ruang Angkasa Yang Dilakukan Oleh Perusahaan Swasta. Jurnal Hukum. Vol. 12 No. 28. Januari 2005. hal. 116-117. 
pemberian bantuan kepada astronot dan pemberitahuan mengenai adanya gejala-gejala yang membahayakan di ruang angkasa sert amengembalikan astronot ke negara peluncur.

Dalam Outer Space Treaty 1967 dan Rescue Agreement 1968, bahwa apabila terjadi kecelakaan yang merugikan parah pihak atau pihak ketiga, maka negara yang meluncurkan objek keluar angka salah yang wajib memberikan ganti rugi kepada pihak yang mengalami kerugian, tetapi tidak diatur bagaimana pemberian ganti rugi bagi yang mengalami kerugian jika pihak swasta yang menyebabkan kerugian atau jika pihak swasta yang menyelenggarakan peluncuran objek keluar angkasa.

Artikel ini akan fokus membahas tentang Bagaimana tanggung jawab perusahaan dalam kegiatan wisata ruang angkasa apabila terjadi kecelakaan dalam kegiatan wisata luar angkasa ditinjau berdasarkan Treaty On Principle Governing The Activities Of State In The Exploration And Uses Outer Space Including The Moon And Other Celestial Bodies Atau Outer Space Treaty 1967.

\section{B. Pembahasan}

Priyatna Abdurrasyid menggunakan istilah 'angkasa' untuk pengertian yang lebih luas, yaitu ruang yang terdiri dari ruang udara dan ruang angkasa. Dengan pengertian tersebut, maka Priyatna memakai peristilahan hukum yang mengatur mengenai ruang udara disebut hukum udara (air law) dan hukum yang mengatur ruang angkasa disebut hukum ruang 
angkasa (space law), sedangkan untuk kedua-duanya disebut sebagai hukum angkasa. ${ }^{7}$

Istilah antariksa baru dikenal sejak dikeluarkannya Keputusan Presiden tentang Dewan Penerbangan dan Antariksa Nasional Republik Indonesia (DEPANRI) dan Keputusan Presiden tentang Lembaga Penerbangan dan Antariksa Nasional (LAPAN), kemudian ditetapkan definisinya pada Konsepsi Kedirgantaraan Nasional tahun 1998 (KKN tahun 1998) sebagai hasil sidang Paripurna Kedua DEPANRI. Dalam Konsepsi tersebut dinyatakan bahwa Antariksa adalah ruang beserta isinya yang terdapat di luar ruang udara, serta yang mengelilingi dan melingkupi ruang udara. ${ }^{8}$

Berdasarkan Pasal 1 IGA 1998, dikatakan bahwa ISS selain digunakan untuk kegiatan ilmiah dan teknologi, ISS juga dapat digunakan untuk tujuan komersial dan salah satunya dengan melalui kegiatan wisata ruang angkasa. kegiatan wisata ruang angkasa yang dimaksud adalah jenis wisata orbital spaceflight, yang menjadikan ISS sebagai tempat menginap para wisatawan selama kegiatan wisata ruang angkasa.

Sekalipun diperuntukan untuk kegiatan komersial sebagai destinasi wisata, ISS masih perlu membutuhkan persetujuan dari seluruh anggota yang masuk dalam rezim ISS melalui Multilateral Coordination Board (MCB). Dalam

7 Mardianis. Hukum Antariksa. Jakarta: Raja Grafindo Persada. 2016. hal. 1.

$8 \quad$ Ibid 2.

Uti Possidetis: Journal of International Law, Vol. 2, No. 2 (2021) 
persetujuan tersebut, selain memberikan kebebasan kepada wisatawan atau astronot non-profesional untuk mengunjungi ISS, melalui Multilateral Crew Operations (MCOP) dibentuk pula ketentuan mengenai kriteria terhadap seleksi, pelatihan, tugas dan sertifikasi terkait orang-orang yang akan mengunjungi ISS, termasuk semua penumpang yang merupakan astronot non-profesional atau wisatawan antariksa yang disetujui pada Juni 2001. Ketentuan yang dimaksud adalah Principles Regarding Process and Criteria for Selection, Assignment, Training and Certification of ISS (Expedition and Visiting) Crewmembers, (Principles Regarding Process and Criteria for Selection, Assignment, Training and Certification of ISS).

Jenis-jenis kegiatan wisata ruang angkasa diantaranya; pertama, Orbital Spaceflight yaitu merupakan kegiatan wisata ruang angkasa menggunakan pesawat ruang angkasa yang menawarkan untuk membawa wisatawan ruang angkasa hingga berada pada lintasan orbit di ketinggian tertentu. Tujuan dari kegiatan wisata ruang angkasa adalah untuk merasakan suasana ruang angkasa dalam waktu yang lama dan bahkan bisa mengitari bumi berulang kali karena pesawat yang digunakan untuk orbital spaceflight adalah pesawat yang bisa digunakan untuk berevolusi mengelilingi bumi. Kedua, Sub- Orbital spaceflight yaitu merupakan peluncuran dengan menggunakan pesawat ruang angkasa ke suatu lintasan orbit yang memotong bumi. Wisatawan yang menggunakan jenis 
wisata ini hanya merasakan antariksa pada suatu ketinggian tertentu di atas permukaan bumi, lalu dalam waktu yang relatif singkat akan kembali ke bumi dengan memanfaatkan gaya gravitasi bumi. Jenis wisata ruang angkasa ini hanya bertujuan untuk membawa seseorang merasakan sensasi gravitasi nol (zero gravity) dan pemandangan antariksa dalam waktu singkat. Sehingga apabila sudah mencapai ketinggian tertentu, pesawat ruang angkasa yang digunakan akan kembali ke bumi. Untuk jenis wisata ruang angkasa ini, pesawat ruang angkasa yang digunakan tidak dapat berputar mengelilingi bumi.

Hukum ruang angkasa yang berlaku saat ini dan merupakan rumah besar dari pengaturan mengenai keruangangkasan adalah Space Treaty 1967. Sejarah panjang pembentukan Space Treaty 1967 adalah berawal pada tanggal 15 Maret 1958, Amerika Serikat meminta agar Majelis Umum PBB membentuk Ad Hoc Komite Penggunaan Damai Antariksa (AD-COPUOS). AD-COPUOS (Ad Hoc Committee on the Peacefull Uses of Outer Space) dibentuk pada tahun 1958 dan menjadi badan permanen PBB pada tahun berikutnya. Saat ini, kelompok ini dikenal sebagai "COPUOS". COPUOS adalah forum internasional utama bagi pengembangan hukum dan prinsip-prinsip yang mengatur antariksa. COPUOS dibebankan dengan menyelidiki masalah hukum dan politik yang ditimbulkan oleh penggunaan antariksa dan menentukan 
peran apa yang harus dimainkan PBB yaitu COPUOS sendiri dalam memecahkan masalah tersebut. ${ }^{9}$

Melalui serangkaian pembahasan yang berlangsung pada sidang-sidang UNCOPUOS (United Nations Committee on the Peaceful Uses of Outer Space), konsep prinsip-prinsip tersebut terus dikembangkan. Pada akhirnya, Majelis Umum PBB dengan Resolusi Nomor 2222 (XXI), 19 Desember 1966, menerapkan Traktat mengenai prinsip-prinsip yang Mengatur Kegiatan Negara-negara dalam Eksplorasi dan Penggunaan Antariksa, Termasuk Bulan dan Benda Langit Lainnya ("Treaty on Principles Governing the Activities of States in the Exploration and Use of Outer Space, including the Moon and Other Celestial Bodies"), yang selanjutnya disingkat Perjanjian Antariksa, 1967. Perjanjian Antariksa ini terbuka untuk ditandatangani negara-negara sejak sejak 27 Januari 1967 dan diberlakukan sebagai hukum positif (entry into force) sejak 10 Oktober 1967, sehingga sering kali Traktat ini disingkat dengan istilah bahasa Inggris Outer Space Treaty, 1967.10

Outer Space Treaty 1967 adalah hukum dasar bagi terciptanya hukum-hukum selanjutnya dalam masalah aktivitas manusia di ruang angkasa termasuk bulan dan benda-benda langit lainnya. Di dalam Space Treaty 1967 terdapat prinsip-prinsip yang digunakan oleh PBB melalui Komite Pemanfaatan Ruang Angkasa untuk Tujuan Damainya

\footnotetext{
9 Mardianis. Op.cit. hal 111.

10 Ibid. hal. 111.
}

Uti Possidetis: Journal of International Law, Vol. 2, No. 2 (2021) 
Tanggung Jawab Perusahaan dalam Komersialisasi Ruang...

(United Nations Committee on the Peaceful Uses of Outer Space) untuk menciptakan suatu aturan hukum internasional mengenai kegiatan di ruang angkasa, yaitu:

1) Agreement on the Rescue of Astronauts, the Return of Astronauts and the Return of Objects Launched into Outer Space 1968 atau Rescue Agreement 1968.

2) Convention on International Liability for Damage Caused by Space Objects 1972 atau Liability Convention 1972.

3) Convention on Registration of Objects Launched into Outer Space 1975 atau Registration Convention 1975.

4) Agreement Governing the Activities of States on the Moon and Other Celestial Bodies 1979 atau Moon Agreement 1979.

Hingga saat ini masih belum terdapat konvensi internasional yang secara eksplisit mengatur tentang kegiatan wisata ruang angkasa, akan tetapi ada beberapa kaitan antara penyelenggaraan wisata ruang angkasa beserta perlindungan hukum terhadap wisatawan ruang angkasa dengan konvensi yang telah ada, diantaranya:

1) Treaty on Principles Governing the Activities of States in the Exploration and Use of Outer Space, including the Moon and Other Celestial Bodies (Outer Space Treaty 1967), konvensi ini merupakan pedoman dalam 
kegiatan-kegiatan yang dilakukan di antariksa, baik yang bersifat kenegaraan atau komersial yang dilakukan dengan tujuan damai.

2) Convention on International Liability for Damage Caused by Space Objects (Liability Convention 1972), konvensi ini merupakan perpanjangan dari Pasal VII dalam Outer Space Treaty 1967. Pada Pasal VII diatur mengenai kewenangan negara atas objek yang diluncurkan ke ruang angkasa atau kerugian yang didapat negara lain karena objek yang diluncurkan ke ruang angkasa. Hal-hal itu yang membuat negara pemilik obyek tersebut harus bertanggung jawab atas kerugian yang terjadi berdasarkan pada Pasal 1 Liability Convention 1972.11

Berdasarkan konvensi ini, terdapat dua prinsip tanggung jawab:

a. Absolute Liability, yaitu suatu negara jelas bersalah atas kerugian obyek antariksa yang jatuh atau menimbulkan kerugian pada suatu permukaan bumi yang berakibat pada kerugian di suatu negara sehingga negara memiliki kewajiban untuk bertanggung jawab atas kerugian tersebut (Pasal 2 Liability Convention 1972).

b. Liability Based on Fault, yaitu apabila sebuah benda yang diluncurkan ke antariksa oleh suatu negara

11 Lihat Liability Convention 1972

Uti Possidetis: Journal of International Law, Vol. 2, No. 2 (2021) 
jatuh di permukaan bumi, maka perlu dibuktikan berdasarkan akibat-akibat yang ditimbulkan dari jatuhnya obyek ruang angkasa tersebut, apabila memang terbukti bersalah maka nantinya negara bisa melakukan pertanggungjawaban (Pasal 3 Liability Convention 1972).

Terkait dengan kegiatan wisata antariksa, maka Liability Convention 1972 memberikan ketentuan dasar tentang tanggung jawab negara atas peluncuran yang dilakukan oleh pihak swasta. Akan tetapi, terhadap kegiatan wisata ruang angkasa hanya dijelaskan secara implisit, terkait dengan kegiatan wisata ruang angkasa, tanggung jawab yang ada hanyalah seputar bendabenda atau objek ruang angkasa (misalnya pesawat ruang angkasa) bukan yang berkaitan dengan masalah subjek hukumnya yaitu wisatawan ruang angkasa yang melakukan perjalanan wisata ruang angkasa.

3) Convention on Registration of Objects Launched into Outer Space (Registration Convention 1975), yaitu pada Pasal 1 Registration Convention 1975, dijelaskan bahwa tujuan dari konvensi ini dibentuk adalah untuk memudahkan mekanisme terhadap registrasi objek ruang angkasa, seperti satelit dan benda-benda antariksa yang dimiliki oleh suatu negara tertentu. Konvensi ini merupakan penjabaran dari Pasal VIII Outer Space Treaty 1967. 
Pada Pasal 2 Registration Convention 1975, diatur bahwa negara peluncur yang akan meluncurkan objeknya ke ruang angkasa perlu mendaftarkan objek ruang angkasanya. Pendaftaran objek ruang angkasa dianggap hal penting karena tanda kebangsaan negara yang mendaftarkan objek ruang angkasa dan juga menimbulkan ikatan yuridis dengan negara tempatnya terdaftar dan merupakan titik taut tanggung jawab negara dengan objek ruang angkasa.

Apabila dikaitkan dengan wisata ruang angkasa, maka pihak swasta yang mengadakan peluncuran wisata ruang angkasa harus melalui prosedur yang sama atas semua objek yang akan diluncurkan ke ruang angkasa. hal tersebut terkait dengan pesawat ruang angkasa yang menjadi pesawat penumpang bagi wisatawan ruang angkasa yang akan diluncurkan. ${ }^{12}$

Setiap kegiatan yang dilakukan di ruang angkasa harus berdasarkan prinsip-prinsip hukum ruang angkasa. Prinsip utama Outer Space Treaty antara lain, Non appropriation principle dan Freedom exploitation principle. Kedua prinsip utama ini dijelaskan dalam Outer Space Treaty 1967. Freedom exploitation principle, yaitu merupakan prinsip yang menjelaskan bahwa antariksa, termasuk bulan dan bendabenda langit lainnya adalah zona bebas untuk melakukan

\footnotetext{
${ }^{12}$ Lihat Registration Convention 1975.
} 
eksplorasi dan eksploitasi oleh semua negara yang ada, sepanjang penggunaannya untuk tujuan damai.

Sedangkan Non appropriation principle, ${ }^{13}$ yaitu prinsip yang menjelaskan bahwa antariksa, termasuk bulan dan benda-benda langit lainnya merupakan milik bersama umat manusia, yang artinya tidak dapat diakui atau diklaim berada dibawah kedaulatan suata negara manapun.

Untuk menganalisis apakah Pasal 5 Outer Space Treaty ini dapat diterapkan pada wisatawan ruang angkasa jika terdapat kecelakaan, kesulitan atau pendaratan darurat dalam kegiatan wisata ruang angkasa, maka dapat menggunakan Pasal 31 Konvensi Wina 1969.14 Pasal 31 dan 32 dalam Konvensi Wina 1969 dianggap melambangkan kebiasaan internasional yang sduah ada dan berlaku sebelum tahun 1969 dan mengikat semua. Oleh sebab itu, aturan dalam kedua pasal

13 Prinsip ini merupakan prinsip utama dan norma dasar (Grundnorm) dalam Outer Space Treaty 1967. Lihat Zachos A Paliouras. The Non-Appropiation Principle: The Grundnorm of International Space Law. Leiden Journal of International Law, Volume 27. Issue 1. 2014. hal 37-54 https://doi.org $\not 10.1017 /$ S0922156513000630

14 Pasal 31 Konvensi Wina 1969 menyatakan "Suatu Perjanjian ditafsirkan dengan iktikad baik sesuai dengan pengertian yang lazim diberikan terhadap istilah-istilah dari perjanjian sesuai konteksnya dan berdasarkan maksud dan tujuan dari perjanjian tersebut". LIhat Anthony Aust, "Modern Treaty Law and Practice". Cambridge University Press. 2007. hal. 232. Lihat juga Oliver Dorr. "Section 3: Application of Treaties". dalam Vienna Convention on the Law of Treaties; A Commentary. Springer. New York. hal. 562.

Uti Possidetis: Journal of International Law, Vol. 2, No. 2 (2021) 
ini dapat diterapkan untuk perjanjian-perjanjian yang berada di luar Konvensi Wina 1969.15

Apabila mempergunakan metode penafsiran seperti dalam Pasal 31 Konvensi Wina 1969, maka harus dicari makna yang lazim dari teks tersebut dan konteks dari perjanjian Outer Space Treaty mencakup hal apa saja. Melihat dari konteksnya, bahwa semua orang yang dianggap layak untuk melakukan penerbangan ke ruang angkasa dan memakai protokol / ketentuan seperti lazimnya astronot, maka layak di persamakan dengan astronot.

Selain menggunakan interpretasi perjanjian internasional harus dilakukan dengan itikad baik, pernyataan dari NASA (National Aeronautics and Space Administration) serta Federasi Aerosport International yang mengatakan setiap wisatawan ruang angkasa yang telah melakukan penerbangan hingga ketinggian di atas 62 mil atau 100 kilometer akan disematkan Wing Astronot sesuai dengan standar FAA dan dapat disamakan dengan astronot. Karena disamakannya status wisatawan dengan astronot, maka wisatawan ruang angkasa mendapatkan perlindungan seperti yang dicantumkan di dalam Resceu Agreement 1968 dan mendapatkan tanggung jawab oleh negara dan kompensasi, mengingat pelaksanaan wisata ruang angkasa oleh perusahaan swasta tidak akan terjadi tanpa adanya izin dari pihak negara,

15 Ibid. Dorr. hal. 563.

Uti Possidetis: Journal of International Law, Vol. 2, No. 2 (2021) 
maka negara tetap harus melakukan tanggung jawab apabila terjadi kecelakaan terhadap wisatawan ruang angkasa.

Dalam hukum nasional maupun internasional terdapat sebuah asas hukum yang menyatakan, lex posterior derogat legi priori yaitu asas penafsiran hukum yang menjelaskan bahwa hukum yang terbaru (lex posterior) mengesampingkan hukum yang lama (lex prior). Maka Rescue Agreement dapat mengesampingkan Pasal 5 Outer Space Treaty. ${ }^{16}$ Menurut Bin Cheng, pengertian astronot dalam arti yang lazim, dapat diperluas termasuk setiap orang yang berada dalam pesawat ruang angkasa termasuk wisatawan ruang angkasa. ${ }^{17}$ Kata "personnel" terdapat dalam Pasal 1-4 Resceu Agreement, yang dapat menjadi dasar hukum penyelamatan wisatawan ruang angkasa jika mengalami kecelakaan dalam kegiatan wisata ruang angkasa.

Tidak adanya perbedaan antara penerbangan privat dan publik dalam Rescue Agreement juga dapat memperluas interpretasi yang diminta negara mengenai personnel swasta (non-govermental personnel) dan mengembalikan pesawat ruang angkasa privat (private space aircraft). Jadi, kata personnel dapat diperluas artinya termasuk wisatawan ruang angkasa.

16 Aryuni Yuliatiningsih. Aspek Hukum Kegiatan Wisata Ruang Angkasa (Space Tourism) menurut Hukum Internasional. Jurnal Dinamika Hukum. Vol. 11. No. 1. 2011. hal. 157.

17 Bin Cheng. "Space Object". Astronouts and Related Expression in Proceeding of Thirty-Fourth Colloquium on the Law of Outer Space. 
Tanggung jawab perusahaan penyedia jasa kegiatan wisata ruang angkasa apabila terdapat kerugian yang diderita wisatawan dalam konvensi yang ada saat ini baik di dalam Outer Space Treaty atau Liability Convention memang hanya mengatur soal ganti rugi atau tuntutan. Jika perusahaan sudah melakukan ganti rugi maka tidak ada akibat hukum lain yang diterima oleh perusahaan penyedia jasa kegiatan wisata ruang angkasa tersebut.

\section{Penutup}

Outer Space Treaty 1967 secara umum, mengatur dasar-dasar hukum mengenai kegiatan eksplorasi di ruang angkasa, antara lain mengenai hak dan kewajiban negara sebagai negara peserta perjanjian, mengenai tanggung jawab negara untuk memberikan izin dan melakukan pengawasan terhadap kegiatan eksplorasi ruang angkasanya, terkait dengan tanggung jawab negara untuk melakukan perlindungan hukum dalam kegiatan eksplorasi dan penggunaan antariksa. Ketentuan hukum yang berkaitan dengan kegiatan wisata ruang angkasa masih tidak bisa terlepas dari ketentuan-ketentuan umum hukum ruang angkasa yang ada, seperti ketentuan-ketentuan yang terdapat dalam Outer Space Treaty, Liability Convention, Rescue Agreement, Registration Convention baik secara langsung maupun tidak langsung. 
Implikasi pertanggungjawaban bagi perusahaan penyedia jasa kegiatan wisata ruang angkasa terhadap wisatawan yang mengalami kerugian dalam kegiatan wisata ruang angkasa saat ini hanya sebatas tentang perihal ganti rugi. Akibat hukum lain bagi perusahaan apabila menyebabkan kerugian saat ini tidak diatur dalam Outer Space Treaty atau Liability Convention.

Dalam kegiatan wisata ruang angkasa antara wisatawan dan penyedia jasa kegiatan wisata ruang angkasa juga terdapat kontrak yang harus dibuat sebelum wisatawan melakukan perjalanan antariksa. Dalam kontrak tersebut harus dengan jelas diuraikan tentang hak dan kewajiban perusahaan selaku pengangkut dan yang penting juga harus diuraikan tentang tanggung jawab perusahaan pengangkut apabila terjadi kecelakan dalam kegiatan wisata ruamg angkasa. Sehingga kontrak antara perusahaan pengangkut dengan wisatawan merupakan aturan khusus dari tanggung jawab perusahaan pengangkut yang terdapat dalam Outer Space Treaty atau Liability Convention. 


\section{Referensi}

\section{Instrumen Hukum}

Agreement on the Rescue of Astronauts, the Return of Astronauts and the Return of Objects Launched into Outer Space 1968 disingkat Rescue Agreement 1968.

Convention on International Liability for Damage Caused by Space Objects 1972 disingkat Liability Convention 1972.

Convention on Registration of Objects Launched into Outer Space 1975 disingkat Registration Convention 1975.

Treaty on Principles Governing the Activities of States in the Exploration and Use of Outer Space, including the Moon and Other Celestial Bodies 1967 disingkat The Outer Space Treaty 1967.

The Vienna Convention to the law of Treaties 1969.

\section{Buku}

Aust, Anthony. Modern Treaty Law and Practice, Cambridge: Cambridge University Press. 2007.

Bahar, Wahyudi. Pertanggungjawaban Negara Terhadap Kegiatan Komersial di Ruang Angkasa dalam Hukum Angkasa dan Perkembangannya, edisi E. Saefullah Wirapradja, et. al. Bandung: Remadja Karya. 1998.

Mardianis. Hukum Antariksa. Jakarta: Raja Grafindo Persada. 2016.

\section{JURNAL DAN ARTIKEL ILMIAH}

Cheng, Bin. "Space Object", Astronouts and Related Expression in Proceeding of Thirty-Fourth Colloquium on the Law of Outer Space. 
Q, Collins P. Ashford D.M. "Potential Economic Implications of The Development of Space Tourism", Acta Astronautica, April 1988.

Yuliatiningsih, Aryuni. Aspek Hukum Kegiatan Wisata Ruang Angkasa (Space Tourism) menurut Hukum Internasional. Jurnal Dinamika Hukum, Vol. 11, No. 1. 2011.

\section{Website}

Elizabeth Howell, “Virgin Galactic: Richard Branson's Space Tourism Company", https://www.space.com/18993-virgingalactic.html.

Redaksi Kumparan, "6 Perusahaan Swasta Ini Berlomba Tawarkan Wisata ke Luar Angkasa", https://kumparan.com / @ kumparansains/6-perusahaan-swasta-ini-berlombatawarkan -wisata-ke-luar-angkasa. 